Standing up for the medical rights of asylum seekers

\section{Standing up for the medical rights of asylum seekers}

\section{Richard E Ashcroft}

\section{When denial of medical treatment is being used as a lever to move people out of the country, ethicists and healthcare professionals should speak out.}

A n ugly feature of political life throughout the Western world, and beyond, is the suspicion towards, and maltreatment of, migrants from poor to rich countries. People who would otherwise be horrified at being labelled racist nevertheless find it acceptable to support practices which can range from stigmatisation (for instance through requiring failed asylum seekers to pay for basic necessities not with money but with vouchers) to confinement in brutalising conditions in "reception" and "removal" centres. ${ }^{1-5}$

An hour spent searching through government and NGO websites concerned with the treatment of asylum seekers and refugees in developed world countries is an hour well spent - but profoundly depressing. This is not only because of the frankly Orwellian language used by the governments of the UK and Australia (for instance), or because of the conditions and treatment meted out, but also because of the apparent support these practices have among the voting public. In the pointedly optimistic reports of Her Majesty's Inspector of Prisons, for example, one can find praise for the fact that at one removal centre "routine strip searches" have now stopped, alongside recognition that accommodation conditions were "simply unacceptable" (HMIP Report on IRC Haslar, p 5) ${ }^{3}$ Yet the UK government's "Myth Busting Leaflet" is exclusively concerned with the worries of those who think asylum seekers are being treated too well: assuring citizens that adult asylum seekers are given less benefits than permanent residents, and do not receive better housing or material goods. ${ }^{6}$ Similarly, in Australia, the current government has consistently made political capital from being seen to be "tough" on asylum seekers. ${ }^{4}$

The issue of migration between countries has been politically contentious now for many years in most developed countries, as they have been forced to confront the legacy of the conditions under which they became developed, and the dramatic inequalities in wealth between developed and underdeveloped countries. Some have argued that for a variety of reasons, including economic growth, restorative justice, and difficulties in consistently holding both that liberal democracy is the only morally legitimate form of government and that barriers on immigration are justifiable, we should abandon our current restrictions on free movement between countries. ${ }^{8}$ Y Yet even if, on mature reflection, one does not share this position, it is shaming to live in a country which not only mistreats migrants in these ways, but even sees political parties appeal for votes on the basis that the public actively support them in doing so.

The treatment of asylum seekers is a medical ethical issue. Firstly, the conditions of detention of some asylum seekers, especially those whose application for asylum has been refused, are not only distressing to us, they can induce or worsen pre-existing psychiatric disorders in them. ${ }^{10}{ }^{11}$ Secondly, not only do doctors with care of asylum seekers have a responsibility to do the best they can for their patients, they also have responsibilities to ensure that detainees in reception and removal centres, and asylum seekers in the community, have proper access to the health care they need, and to speak out about the conditions which worsen their patients' health, and the public health implications of inadequate or inhumane treatment. $^{512}$ Thirdly, the social and ethical issues relating to the treatment of asylum seekers are issues which have a resonance with general issues about the human right to health, and the economic and social right to healthcare..$^{13} 14$

The UK government has recently "tightened up" the rules regarding access to free treatment on the National Health Service by overseas visitors, including asylum seekers and

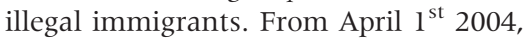
asylum seekers whose application has been refused and for whom all appeals have been exhausted are to be charged for all non-emergency care, with some specified exceptions concerning compulsory psychiatric treatment and a list of infectious diseases (not including HIV). ${ }^{15}$ Since they are not permitted to work, and may be receiving no other benefits, it is hard to see how this is possible. ${ }^{16}$ Although this has been official policy so far as hospital care is concerned since 1989, it has been applied only haphazardly. While the extension of this policy to primary care is currently merely under consultation, the extended guidelines are already in place, and with some fanfare the government has announced its intention to apply this policy rigorously even before this consultation. ${ }^{17} 18$ Laughably, the official guidance to NHS Trusts states that to avoid claims of race discrimination, everyone should be asked the same questions about where they have lived for the past 12 months, and whether they can show the right to live here. ${ }^{19}$ It is more important to appear nondiscriminatory than actually to be nondiscriminatory. More seriously still, doctors are being put into the position of having to decide whether or not to treat a patient, not on medical grounds, but on the grounds of whether the patient has the right papers and or the right illness. ${ }^{20}$

Critics of laxity asylum rules will argue that all this is as it should be. Yet when denial of medical treatment, even to people with genuine medical need, is being used as a lever to move people out of the country, ethicists and healthcare professionals should speak out. Systems which ensure poor quality or denial of service to one vulnerable group, merely pour encourager les autres, diminish and threaten us all.

J Med Ethics 2005;31:125-126.

doi: 10.1136/jme.2005.011742

Correspondence to: R E Ashcroff, Imperial College London, Medical Ethics Unit, Reynolds Building, St Dunstan's Road, London W6 8RP; r.Ashcroft@imperial.ac.uk

This editorial was written while the author was a Visiting Fellow at the Centre for Applied Philosophy and Public Ethics, University of Melbourne. The visit was funded by an Australian Bicentennial Fellowship.

\section{REFERENCES}

1 MORI. Attitudes towards Asylum Seekers for 'Refugee Week'. 17-06-2002. http:// www.mori.com/polls/2002/refugee.shtml (accessed 21 January 2005).

2 Immigration and Naturalisation Directorate. PB 53 - Temporary Support for NASS Eligible Disbenefited Singles http:// www.ind.homeoffice.gov.uk/ind/en/home/ applying/national_asylum_support/ stakeholders/policy_bulletin/ temporary_support.html (accessed 21 January 2005)

3 HM Inspector of Prisons Report on an Unannounced Inspection of Haslar Immigration 
Removal Centre 29-31 March 2004. London: HMIP, 2004.

$4 \mathrm{HM}$ Inspector of Prisons Report on an Announced Inspection of Oakington Immigration Reception Centre 21-25 June 2004. London: HMIP, 2004.

5 McNeill PM. Public health ethics: Asylum seekers and the case for political action. Bioethics 2003; 17:487-502.

6 National Asylum Support Service. Dispelling the Myths, Telling the Facts: The Facts About Support for Asylum Seekers. London: The Home Office, 2004.

7 Kenny MA, Silove DM, Steel Z. Legal and ethical implications of medically enforced feeding of detained asylum seekers while on hunger strike. Med J Australia 2004;180:237-240.

8 Dummett M. On Immigration and Refugees. London: Routledge, 2001.

9 Cole P. Philosophies of Exclusion: Liberal Political Theory and Immigration. Edinburgh: Edinburgh University Press, 2000.

10 Keller AS, Rosenfeld B, Trinh-Shevrin C, et al. Mental health of detained asylum seekers. Lancet 2003;362:1721-1723.

11 Loff B. Detention of asylum seekers in Australia. Lancet 2002;359:702-703.

12 Physicians for Human Rights. Dual Loyalty and Human Rights in Health Professional Practice:
Proposed Guidelines and Institutional Mechanisms. Boston, Mass: Physicians for Human Rights, 2003.

13 United Nations. Universal Declaration of Human Rights. (1948) http://www.un.org/ Overview/rights.html (accessed 21 January 2005).

14 United Nations. International Covenant on Economic, Social and Cultural Rights. (1966) http://www.unhchr.ch/html/menu3/b/ a_cescr.htm (accessed 21 January 2005).

15 Department of Health. Entitlement to NHS Treatment (Correct at April $7^{\text {st }} 2004$ Onwards) http://www.dh.gov.uk/PolicyAndGuidance/ International/AsylumSeekersAndRefugees/fs/en (accessed 21 January 2005).

16 Immigration and Naturalisation Directorate. Instructions to Caseworkers: Failed Asylum Seekers - Withdrawal of Support. Paragraph 7A of Schedule 3 of the Nationality, Immigration and Asylum Act 2002 (as inserted by section 9 Asylum and Immigration (Treatment of Claimants, Etc.) Act 2004) London: The Home Office, 2004. http:// www.ind.homeoffice.gov.uk/ind/en/home/ applying/asylum_applications.html? (accessed 21 January 2005)
17 Department of Health. Proposals to exclude overseas visitors from eligibility to free NHS primary medical services; A consultation. London: Department of Health, 2004. http:// www.dh.gov.uk/Consultations/

ClosedConsultations/ClosedConsultationsArticle/ fs/en?CONTENT_ID = 4087618\&chk = YGIMPh (accessed 21 January 2005).

18 Department of Health. Hutton proposes tighter NHS rules for treating overseas visitors. London: Department of Health, 2003. http:// www.dh.gov.uk/PublicationsAndStatistics/ PressReleases/PressReleasesNotices/fs/ en?CONTENT ID = 4047476\&chk = AbL\%2BD9 (accessed 21 January 2005).

19 Department of Health. Implementing the overseas visitors hospital charging regulations: Guidance for NHS Trust Hospitals in England. London: Department of Health, 2004. http:// www.dh.gov.uk/PublicationsAndStatistics/ Publications/PublicationsPolicyAndGuidance/ PublicationsPolicyAndGuidanceArticle/ $\mathrm{fs}_{\mathrm{s}} /$ en?CONTENT ID = 4080313\&chk=SE4Gro (accessed 21 January 2005).

20 Pollard AJ, Savulescu J. Eligibility of overseas visitors and people of uncertain residential status for NHS treatment. Br Med J

2004:329:346-349.

\section{Call for papers}

The Journal of Medical Ethics is planning to publish a number of thematic issues and invites submissions of original or short papers on the following topics:

Deadline 15 June 2005

Neuroethics

Deadline 15 December 2005

Public Health Ethics

Ethical issues is obstetrics and gynaecology

Multidisciplinary research in medical ethics

Deadline 15 June 2006

Equity and justice in health care

Ethical issues in oncology and palliative care

Teaching ethics to health care students and professionals

If you would like to discuss a possible submission please e-mail Søren Holm at holms@cardiff.ac.uk with your idea. Prior discussion with the editor is not obligatory.

Please state in your submission letter that you would like the paper considered for a thematic issue. 